\title{
Reinnervation of peripheral nerve segments implanted into the hemisected spinal cord estimated by transgenic mice
}

\author{
Y Matsuyama, K Mimatsu, T Sugimura, S Kondou, H Iwata and K Isobe \\ Department of Orthopedic Surgery, and Immunology, Nagoya University School of Medicine, Tsurumai-cho, \\ Showa-ku Nagoya, 466, Japan
}

\begin{abstract}
We investigated how far Schwann cells, which are the peripheral nerve elements supporting axonal regrowth, penetrate into the hemisected recipient spinal cord. C57BL $/ 6$ mice, which carry carcinoembryonic antigen as transgene, were used for transplantation study. These CEA transgenic mice were syngenic to C57BL/6 mice except for the expression of human CEA DNA. In the syngenic transplantation study, C57BL/6 mice were transplanted with the sciatic nerve of CEA-transgenic mice to the hemisected spinal cord. Schwann cell migration into the recipient spinal cord was detected by the PCR method. Transplanted Schwann cells migrated into the recipient spinal cord both rostrally and caudally at a distance of $2 \mathrm{~mm}$ from the graft-host interface until 21 days after transplantation. At 28 days after transplantation, the Schwann cells migrated rostrally at a distance of $2 \mathrm{~mm}$ and caudally at a distance of $4 \mathrm{~mm}$. C57BL/6-CEA sciatic nerve was transplanted to BALB/C mice as the allogenic transplant. CEA DNA was detected until 14 days after transplantation, but disappeared at 21 days. In addition, C57BL/6-CEA sciatic nerves were transplanted into Wistar rats to study xenogenic transplantation. The CEA band disappeared at 10 days after transplantation. In conclusion, by using CEA transgenic mice and the PCR method, we could evaluate the mobility of Schwann cells which are thought to play an important role in axonal regeneration.
\end{abstract}

Keywords: axonal regeneration; CEA transgenic mice; polymerase chain reaction (PCR)

\section{Introduction}

Peripheral nerve (PN) grafting is a widely accepted method of investigating axonal regeneration in the mammalian central nervous system (CNS) ${ }^{1-23}$ PN grafts are thought to provide the central neurons with supportive structures that allow axonal elongation. However such experiments have not revealed the underlying mechanisms that are responsible for the expression of the regenerative potential of central neurons. It has been hypothesised that the PN grafts are sources of neurotrophic factors ${ }^{4,14,16-21,24-26}$ and that Schwann cells play an important role in the projection of PN axons into the host spinal cord as well as in the projection of CNS axons into the transplants. For investigation of the survival of transplanted peripheral nerves as well as development integration and axonal interaction with the spinal cord, three major methods have been used: histological techniques at the light and electron microscopic levels, use of axonal tracers (horseradish peroxidase, fluoro-gold, and Phaseolus vulgalis leucoaggultinin), and immunocytochemical techniques. In the present study, we used the polymerase chain reaction (PCR) method and CEA-transgenic mice 27,28 to evaluate more clearly transplanted syngenic, allogenic and xenogenic peripheral nerve rejection or acceptance as well as how far Schwann cells migrate into the host spinal cord.

\section{Materials and methods}

C57BL/6(B6/H-2 $\left.{ }^{\text {b }}\right)$ mice, BALB $/ \mathrm{C}\left(\mathrm{H}-2^{\mathrm{d}}\right)$ mice, and Wistar rats were purchased from Shizuoka Laboratory Animal Center (Shizuoka, Japan), and human carcinoembryonic antigen transgenic mice (B6-CEA) established by $\mathrm{T}$ Hasegawa in our laboratory were bred at the Institute for Laboratory Animal Research, Nagoya University School of Medicine. C57BL/6 mice, BALB/C mice, and Wistar rats, at 8 weeks of age, were used as the recipients while human carcinoembryonic antigen transgenic mice of the same age were used as the donors in all experiments.

Syngenic transplantation group Sciatic nerve grafts from B6-CEA mice were transplanted into the hemisected spinal cords of C57BL/6 mice.

Allogenic transplantation group Sciatic nerve grafts from B6-CEA mice were transplanted into the hemisected spinal cords of $B A L B / C\left(H-2^{d}\right)$ mice.

Xenogenic transplantation group Sciatic nerve grafts from B6-CEA mice were transplanted into the hemisected spinal cords of Wistar rats. We used four C57BL/6 mice as syngenic recipients, four BALB/ $\mathrm{C}\left(\mathrm{H}-2^{\mathrm{d}}\right)$ mice as allogenic recipients, and four Wistar 
rats as xenogenic recipients. Eight B6-CEA mice were used as sciatic nerve donors.

\section{Surgical technique (recipient surgery)}

The animals were anaesthetized with $4 \%$ chloral hydrate $\left(400 \mathrm{mg} \mathrm{kg}^{-1}\right)$, and laminectomies were made at T8-10 levels. Bleeding from the surrounding bony or soft tissues was controlled with either Gelfoam (Upjohn Japan Co Ltd, Osaka, Japan) (soaked in a solution of bovine thrombin) or epinephrine-impregnated cotton pellets or a microfibriller collagen haemostat. A clean longitudinal incision was then made through the surrounding meninges with a tapered no. 11 scalped blade. Hemisection of the spinal cord (involving resection of a $4 \mathrm{~mm}$ length of tissue) was then performed using iridectomy scissors to cut the spinal cord tissue as it was held by suction with an angled, fine-tipped glass pipette. Haemostasis was subsequently achieved by sponging the wound with thrombin-soaked Gelfoam and gentle aspiration. The resected cavities were then cleared of any blood clots and debris by further sponging with Gelfoam (soaked in saline) and gentle suction. Care was taken to limit damage to the surrounding meningeal sheaths.

\section{Transplantation procedures}

Donor tissue preparation CEA transgenic mice were anaesthetised with chloral hydrate and the right sciatic nerve was exposed under the biceps femoris muscle. After epineurectomy, a $4 \mathrm{~mm}$ long segment of the sciatic nerve was removed and approximated to the transected spinal cord.

Finally, the sciatic nerve segment was placed into the gap in the hemisected spinal cord of the recipient. Coaptation to the spinal cord stumps was secured by fibrin sealant. The leptomeninges and pachimeninges were separately closed with microsurgical nylon sutures (respectively 10-0) and the wounds were closed layer by layer.

DNA primer A pair of DNA primers, 5'-AGCTCACTATTGAATCCACG-3' (primer a) and 5'-TCTCTCGACCACTGTATGCG-3' (primer b), was used to amplify the 194-bp CEA-specific fragment.

\section{Polymerase chain reaction (PCR)}

Recipient mice and rats were anaesthetised with an overdose of $4 \%$ chloral hydrate, and the original wound was reopened. The grafted region was identified by virtue of the non-resorbable sutures, and a second laminectomy was made to expose the spinal cord at various distances either rostral or caudal to the transplant. Then the grafts and the adjacent rostral and caudal stumps of the spinal cord were removed. We performed all surgical procedures under microscopy, so that it was easy to find the boundary between grafted sciatic nerve and host spinal cord. We defined the spinal cord specimens obtained $4 \mathrm{~mm}$ rostral to the graft as $\mathrm{A}, 2 \mathrm{~mm}$ rostral to the graft as B, $2 \mathrm{~mm}$ caudal to the graft as $C$, and $4 \mathrm{~mm}$ caudal to the graft as D (Figure 1). Spinal cord specimen was placed into $1.5 \mathrm{ml}$ microfuge tubes containing $700 \mu \mathrm{l}$ buffer respectively (50 mM Tris, pH 8, $100 \mathrm{mM}$ EDTA, $100 \mathrm{mM} \mathrm{NaCl}$, and $1 \%$ SDS). After mincing the tissue using a pair of scissors, $10 \mathrm{ml}$ of a $10 \mathrm{mg} \mathrm{ml}^{-1}$ solution of Proteinase $\mathrm{K}$ dissolved in $\mathrm{H}_{2} \mathrm{O}$ (Merck 24568, EM Biochemicals, obtained from American Scientific Products) was added, and the sample was incubated at $55^{\circ} \mathrm{C}$ overnight. The tubes were then removed from the incubation, $5 \mu \mathrm{l}$ RNase (Worthington 5679, $5 \mu \mathrm{g}^{-1}$ ) was added, and incubated at $37^{\circ} \mathrm{C}$ for $2 \mathrm{~h}$ to eliminate any contamination of RNA. The tubes were then filled with phenol/chloroform (1:1) and rotated for $5 \mathrm{~min}$. After the $5 \mathrm{~min}$ spin, the aqueous phase was transferred to fresh tubes. This treatment was then repeated. Next an equal volume of $100 \%$ ethanol was added into the tubes, well mixed and spun at $10000 \mathrm{rpm}$ for $5 \mathrm{~min}$. Then the supernatant was removed and washed with $70 \%$ ethanol. The DNA was dried and dissolved with $\mathrm{H}_{2} \mathrm{O}$. The samples were amplified with primer $\mathrm{a}, \mathrm{b}$ and Taq DNA polymerase (Promega, USA). PCR amplification products were evaluated by $2 \%$ agarose gel electrophoresis.

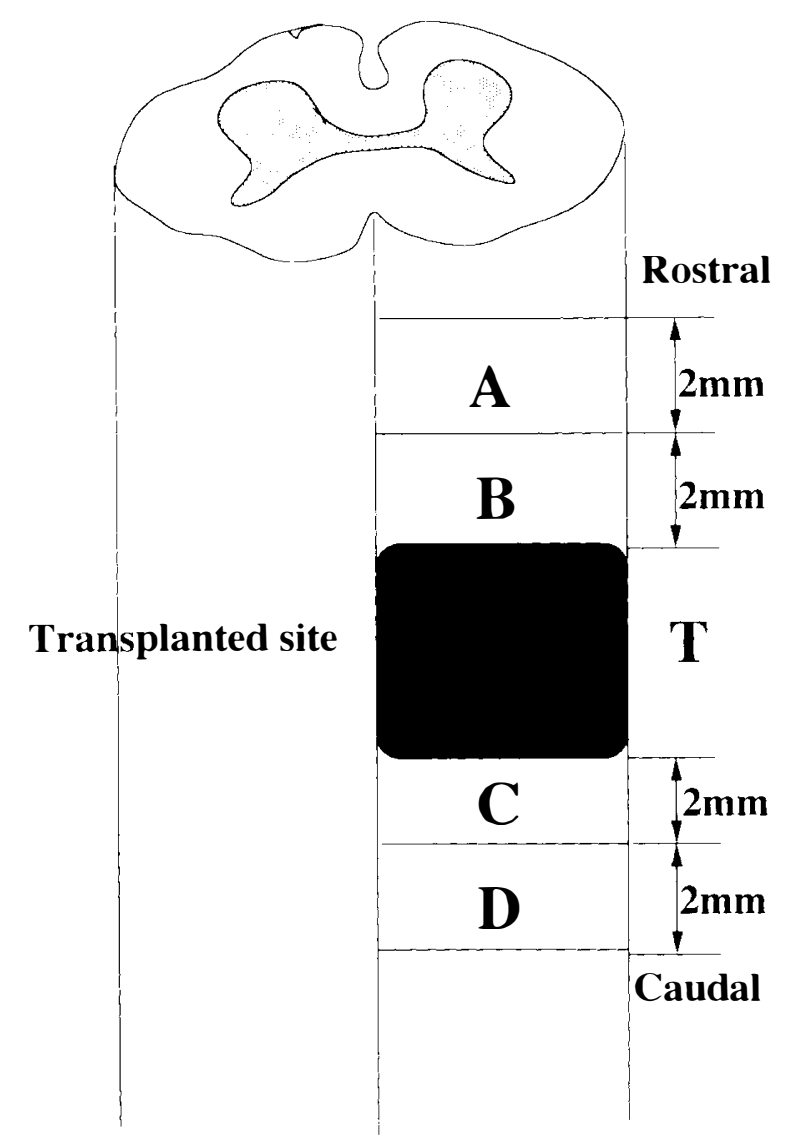

Figure 1 We designated the spinal cord specimens obtained $4 \mathrm{~mm}$ rostral to the graft as A, $2 \mathrm{~mm}$ rostral to the graft as $B, 2 \mathrm{~mm}$ caudal to the graft as $\mathrm{C}$, and $4 \mathrm{~mm}$ caudal to the graft as D. The sciatic nerve graft site was designated as $T$. 


\section{Results}

Migration of Schwann cells into the host spinal cord Syngenic transplantation group Using the PCR method, we evaluated Schwann cell migration into the host spinal cord. Three days after transplantation, a CEA band was detected only in the area T. All four mice showed the same result. At 7 days, 14 days, and 21 days after transplantation, a CEA band was detected in areas $\mathrm{B}, \mathrm{T}$, and $\mathrm{C}$. At these three times, all four mice in each subgroup showed the same result. A CEA band was detected not only in areas $\mathrm{B}, \mathrm{T}$, and $\mathrm{C}$, but also in the area $\mathrm{D}$ at 28 days after transplantation in three of the four mice (Figure 2, Table 1).

Allogenic transplantation group A CEA band was detected only in area $\mathrm{T}$ of the spinal cord at 7 and 14 days after transplantation and no band was detected at 21 days after transplantation in any area of the cord
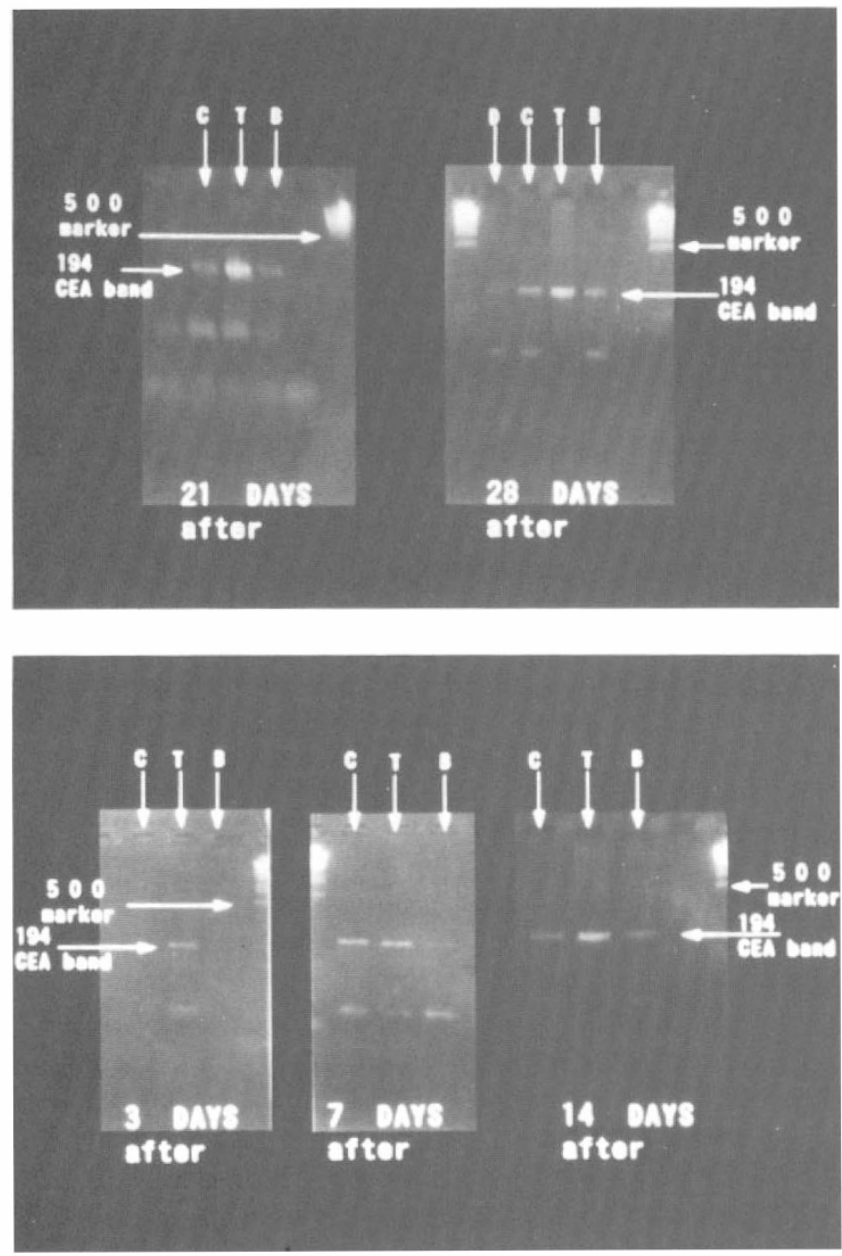

Figure 2 The CEA band-positive area indicates migration of Schwann cells from the CEA transgenic mouse sciatic nerve grafts. Seven, 14, and 21 days after transplantation, migratory Schwann cells derived from CEA transgenic mice had penetrated into areas $B$ and $C$ of the recipient spinal cord. At 28 days after transplantation, migratory Schwann cells had penetrated into areas B, C, and D.
Table 1 This table shows the CEA band-positive rate of each time. A-D and T are different sites in the spinal cord. At 28 days after transplantation, three of four mice $(78 \%)$ were positive in area $\mathrm{D}$

\begin{tabular}{lccccc}
\hline \multirow{2}{*}{$\begin{array}{l}\text { Sites in } \\
\text { spinal cord }\end{array}$} & \multicolumn{5}{c}{ Time } \\
\cline { 2 - 6 } & 3 & 7 & 14 & 21 & 28 \\
& days & days & days & days & days \\
\hline A & $0 / 4$ & $0 / 4$ & $0 / 4$ & $0 / 4$ & $0 / 4$ \\
B & $0 / 4$ & $4 / 4$ & $4 / 4$ & $4 / 4$ & $4 / 4$ \\
T & $4 / 4$ & $4 / 4$ & $4 / 4$ & $4 / 4$ & $4 / 4$ \\
C & $0 / 4$ & $4 / 4$ & $4 / 4$ & $4 / 4$ & $4 / 4$ \\
D & $0 / 4$ & $0 / 4$ & $0 / 4$ & $0 / 4$ & $3 / 4$ \\
\hline
\end{tabular}

(Figure 3). These results were identical in all four mice of each subgroup (Table 2).

Xenogenic transplantation group A CEA band was only detected in area $\mathrm{T}$ of the spinal cord at 5 days after

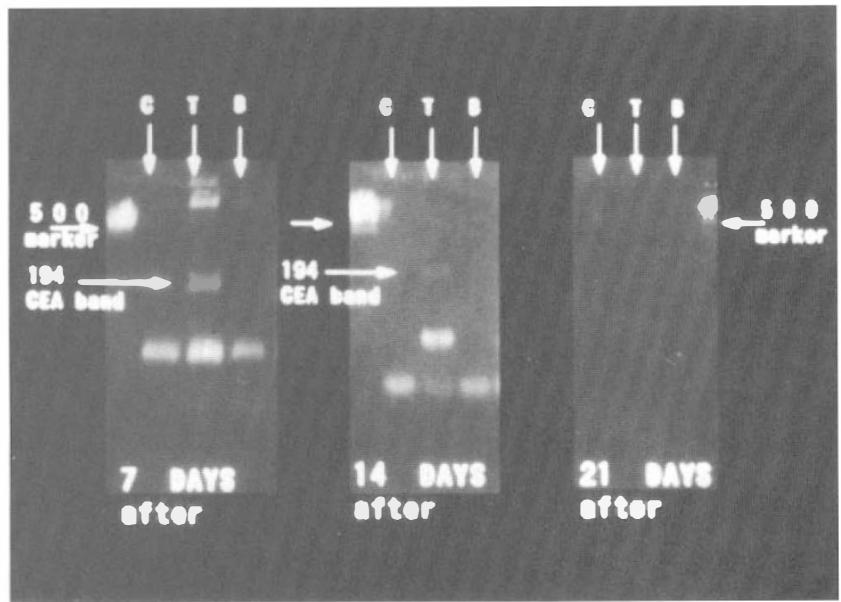

Figure 3 At 7 and 14 days after transplantation, a CEA band was only found in area $\mathrm{T}$ of the recipient spinal cord. This indicated that the allogenic peripheral nerve grafts were not rejected by 14 days after transplantation. However, at $2 i$ days after transplantation, no CEA band was found in any area of the recipient spinal cord, indicating that the allogenic peripheral nerve grafts had been rejected.

Table 2 Allogenic transplantation group. At 7 and 14 days after transplantation, only area $\mathrm{T}$ was positive, while no area was positive at 21 days after transplantation. The results were the same in all four mice

\begin{tabular}{lccc}
\hline Sites in spinal cord & \multicolumn{3}{c}{ Time } \\
\cline { 2 - 4 } & 7 days & 14 days & 21 days \\
\hline $\mathrm{A}$ & $0 / 4$ & $0 / 4$ & $0 / 4$ \\
$\mathrm{~B}$ & $0 / 4$ & $4 / 4$ & $4 / 4$ \\
$\mathrm{~T}$ & $4 / 4$ & $4 / 4$ & $4 / 4$ \\
$\mathrm{C}$ & $0 / 4$ & $4 / 4$ & $4 / 4$ \\
$\mathrm{D}$ & $0 / 4$ & $0 / 4$ & $0 / 4$ \\
\hline
\end{tabular}


xenogenic transplantation, and no band was detected at 10 days after transplantation in any area of the recipient spinal cord (Figure 4). These results were similar in all four mice of each subgroup (Table 3 ).

\section{Discussion}

It has been reported that migratory Schwann cells serve as a gateway in the glial basal lamina for the possible passage of axons, when autologous peripheral nerves are transplanted into the transected spinal cord. ${ }^{1-23}$ These findings were obtained at light and electron microscopic levels. In order to clarify how syngenic transplanted cells migrate into the recipient spinal cord, we used transgenic mice, which carry human CEA cDNA. These CEA transgenic mice were established from a $\mathrm{C} 57 \mathrm{BL} / 6$ inbred strain. The CEA antigen is expressed by every tissue of these animals including the neurons. Although CEA antigen on cells induce anti-CEA antibody, they do not induce anti-CEA killer cells and $\mathrm{T}$ cell proliferation. ${ }^{27,28}$ For these reasons, we could use $\mathrm{C} 57 \mathrm{BL} / 6$ transgenic mice as syngenic donors for $\mathrm{C} 57 \mathrm{BL} / 6$ mice in our graft rejection study. Using

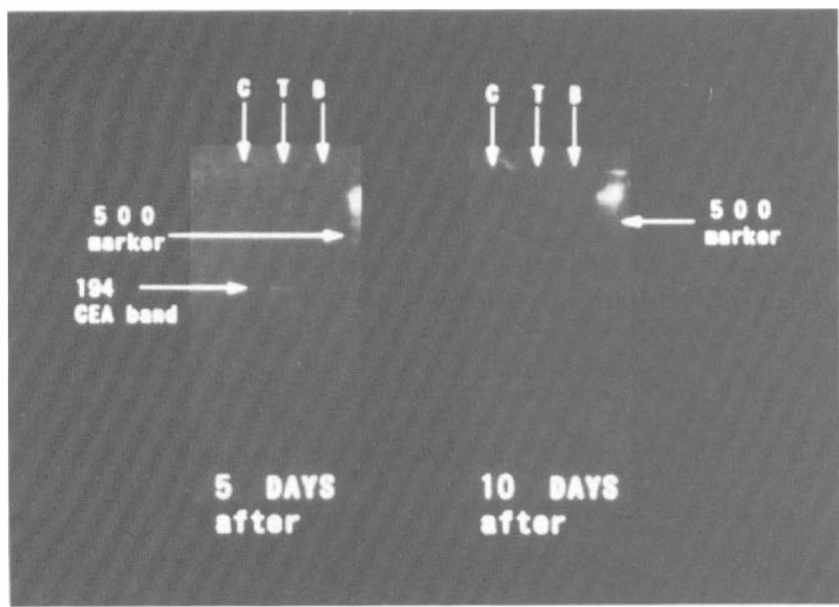

Figure 4 At 5 days after transplantation, a CEA band was only found in area $T$. At 10 days after transplantation, no CEA band was found in any area of the recipient spinal cord. This indicated that it took only 10 days to reject the Xenogenic peripheral nerve grafts.

Table 3 Xenogenic transplantation group. At 5 days after transplantation, only $T$ area was positive, although at 10 days after transplantation no area was positive. The results were the same in all four mice

\begin{tabular}{lcc}
\hline Sites in spinal cord & \multicolumn{2}{c}{ Time after transplantation } \\
\cline { 2 - 3 } & 5 days & 10 days \\
\hline A & $0 / 4$ & $0 / 4$ \\
B & $0 / 4$ & $0 / 4$ \\
T & $4 / 4$ & $0 / 4$ \\
C & $0 / 4$ & $0 / 4$ \\
D & $0 / 4$ & $0 / 4$ \\
\hline
\end{tabular}

the sensitive PCR method, we could detect the expression of CEA cDNA in C57BL/6 mice. Because axons do not contain a nucleus, we consider that the majority of proliferating tissues in areas $\mathrm{A}, \mathrm{B}, \mathrm{C}$ or $\mathrm{D}$ are Schwann cells.

After syngenic transplantation (C57BL/6-CEA to C57BL/6), CEA DNA persisted in the $T$ area of the cord for a long time. However, following allogenic or xenogenic transplantation $(\mathrm{C} 57 \mathrm{BL} / 6 \mathrm{CEA}$ to $\mathrm{BALB} / \mathrm{C}$ or C57BL/6 CEA to Wistar rats), we could not detect CEA DNA after 21 days (allogenic) or 10 days (xenogenic). These findings suggested that the transplanted neuronal tissue (including neurons and Schwann cells) was attacked by the immune system and destroyed. Neurons of xenogenic transplant were more quickly attacked by the immune system than allogenic transplants. The main rejection mechanism of xenogenic transplants has been shown to be complement mediated cytotoxicity, which occurs in the early period after grafting. ${ }^{29}$

The syngenic transplantation study suggested that migratory Schwann cells served as a gateway in the glial basal lamina for the possible passage of axons through the cell. Horvat et al reported that a great number of neurons located bilaterally between $\mathrm{C} 3$ and $\mathrm{C} 7$ in most laminae of the gray matter extended axons into a PN graft. $^{30}$ One week after PN transplantation into the CNS, migratory Schwann cells had penetrated $2 \mathrm{~mm}$ into the recipient spinal cord both rostrally and caudally, possibly allowing axonal regeneration. ${ }^{31}$ Two and 3 weeks after transplantation, the migratory Schwann cells had migrated over the same distance rostrally and caudally into the recipient spinal cord. From 4 weeks after transplantation, migratory Schwann cells had penetrated $2 \mathrm{~mm}$ rostrally and $4 \mathrm{~mm}$ caudally into the spinal cord.

Some interactions between the transplanted neural tissue and the recipient spinal cord have been demonstrated by the presence of both anterogradely labelled fibres and retrogradely labelled neurons in grafts following HRP injection into the recipient spinal cord and the presence of retrogradely labelled neurons in the recipient spinal cord after HRP injection into the graft. Jakerman et al used three anatomical tracers, HRP, fluoro-gold, and Phaseolus vulgaris leucoagglutinin. ${ }^{32}$ They found that axons arising from the transplants extended up to $5 \mathrm{~mm}$ into the recipient spinal cord, and were best revealed by retrograde labeling with fluoro-gold. In the present study, we confirmed the previous findings and further evaluated the distance of Schwann cell migration into the recipient spinal cord using CEA transgenic mice and the PCR method.

Sugar and Gerald, ${ }^{33}$ Windle, ${ }^{34}$ Kao et al, ${ }^{35,36}$ and Richardson et al ${ }^{16-19}$ devised experimental models of axonal regeneration in the adult mammalian spinal cord using autologous peripheral nerve transplants between the stumps of the transected spinal cord and they evaluated the extent of axonal regeneration by only light and electron microscopic study. We found that migration of Schwann cells into the host spinal cord was more accurately evaluated by using the PCR 
method. On the other hand, it remains unclear why the migratory Schwann cells were restricted to a distance of $4 \mathrm{~mm}$ caudal to the graft-host interaction face. Schnell ${ }^{37}$ reported that CNS white matter, oligodendrocytes, and CNS myelin itself, are strong inhibitors of neuronal growth, a property associated with defined myelin membrane proteins of relative molecular mass (Mr) 35,000 (NI-35) and 250,000 (NI-250). We also consider that myelin membrane proteins may be the main inhibitors of neural regrowth and migratory Schwann cell projection. Consequently we are now planning to study axonal regeneration in the presence of neurotrophic factors or myelin-associated neurite growth inhibitor antibodies by using CEA transgenic mice and the PCR method.

\section{Conclusions}

The purpose of this study was to evaluate more clearly transplanted syngenic, allogenic and xenogenic peripheral nerve rejection or acceptance as well as how far Schwann cells migrate into the host spinal cord. Migratory Schwann cells served as a gateway in the glial basal lamina for the possible passage of axons. Migration of Schwann cells into the host spinal cord was more accurately evaluated using the PCR method.

\section{Acknowledgements}

Gratitude is expressed to Dr Yosihiro Nishida for technical assistance.

\section{References}

1 Aguayo AJ, David S, Bray GM. Influences of the glial environment on the elongation of axons after injury: transplantation studies in adult rodents. J Exp Biol 1981; 95: 231-240.

2 Aguayo AJ, David S, Richardson PM, Bray GM. Axonal elongation studied in peripheral and central nervous system transplants. In: Fedoroff S (ed). Advances in Cellular Neurobiology. New York, Academic Press: New York, 1982, pp 215-234.

3 Benfey M, Aguayo AJ. Extensive elongation of axons from rat brain into peripheral nerve grafts. Nature 1982; 296: 150-152.

4 Bray GM et al. Unequal responses of different thalamic neurons to PNS grafts. In: Björklund A, Stenevi V (eds). Neural Grafting in the Mammalian CNS. Fernström Foundation Series, vol 5. Elsevier: Amsterdam, 1985, pp 335-344.

5 Buenger U, Aguayo AJ. Rat visual system neurons grow axons along PNS grafts. Soc Neurosci Abstr 1983; 9: 699.

6 Chi NH, Bignami A, Bich NT, Dahl D. Autologous sciatic nerve grafts to the rat spinal cord. Immunofluorescence studies with neurofilament and gliofilament (GFA) antisera. Exp Neurol 1980; 68: $-568-580$.

7 David S, Aguayo AJ. Axonal elongation into PNS 'bridges' after CNS injury in adult rats. Science 1981; 214: 931-933.

8 Dooley JM, Aguayo AJ. Axonal elongation from cerebellum into PNS grafts in the adult rat. Ann Neurosci 1982; 12: 221.

9 Fernandez E, Pallini R, Minciacchi D, Sbriccoli A. Peripheral nerve autografts to the rat spinal cord: study on the origin and course of regenerating fibers. Acta Neurochir (Wien) 1986; 82: $57-63$.

10 Friedman B, Aguayo AJ. Axonal regeneration from injured axons in the adult rat olfactory bulb. $J$ Neurosci 1985; 5 : 764-773.

11 Keirstead SA et al. Responses to light of retinal neurons regenerating axons into peripheral nerve grafts in the rat. Brain Res 1985; 359: 402-406.

12 Munz $M$ et al. Functional activity of rat brainstem neurons regenerating axons along peripheral nerve grafts. Brain Res 1985; 340: 115-125.

13 Pallini $\mathrm{R}$ et al. Peripheral nerve autografts to the rat spinal cord: A study of the origin of regenerating fibers using fluorescent double labeling. Acta Neurochir Suppl (Wien) 1988; 43: 210-213.

14 Paz Villegas-perez M, Vidal-Sanz M, Bray GM, Aguayo AJ. Influences of peripheral nerve grafts on the survival and regrowth of axotomized retinal ganglion cells in adult rats. $J$ Neurosci 1988; 8: 265-280.

15 Politis MJ, Spencer PS. Regeneration of rat optic axons into peripheral nerve grafts. Exp Neurol 1986; 91: 52-59.

16 Richardson PM, McGuinness UM, Aguayo AJ. Axons from CNS neurons regenerate into PNS grafts. Nature 1980; 284: 264-265.

17 Richardson PM, Ebendal T. Nerve growth activities in the rat peripheral nerve. Brain Res 1982; 246: 57-64.

18 Richardson PM, Mcguinness UM, Aguayo AJ. Peripheral nerve autografts to the rat spinal cord: studies with axonal tracing methods. Brain Res 1982; 237: 147-162.

19 Richardson PM, Issa VMK, Aguayo AJ. Regeneration of long spinal axons in the rat. J Neurocytol 1984; 13: 165-182.

20 Richardson PM, Issa VMK. Peripheral injury enhances central regeneration of primary sensory neurons. Nature 1984; 309: 791-792.

21 Riopelle RJ, Boegman RJ, Cameron DA. Peripheral nerve contains heterogenous growth factors that support sensory neurons in vitro. Neurosci Lett 1981; 25: 311-316.

22 Sceats DJ, Friedman WA, Sypert GW, Ballinger WE. Regeneration in peripheral nerve grafts to the cat spinal cord. Brain Res 1986; 362: 149-156.

23 So KF, Aguayo AJ. Lengthy regrowth of cut axons from ganglion cells after peripheral nerve transplantation into the retina of adult rats. Brain Res $1985 ;$ 328 : 349-354.

24 Abrahamson IK, Wilson PA, Rush RA. Production and transport of endogenous trophic activity in a peripheral nerve following target removal. Brain Res 1986; 27 : 117-126.

25 Heumann R, Korsching S, Bandtlow C, Thoenen H. Changes in nerve growth factor synthesis in non-neuronal cells in response to sciatic nerve transection. J Cell Biol 1987; 104: 1623-1631.

26 Varon S, Manthorpe M, Williams LR. Neuronotrophic and neurite promoting factors and their clinical potential. Dev Neurosci 1984; 6: 73-100.

27 Hasegawa T, Isobe K. Establishment and characterization of human carcinoembryonic antigen transgenic mice. Br J Cancer 1991; 64: 710-714.

28 Hasegawa T, Isobe K. Quantitative analysis of antigen for the induction of tolerance in carcinoembryonic antigen transgenic mice. Immunology 1992; 77: 577-581.

29 Platt JL, Vercelloti GM, Dalmasso AJ, Matas AJ. Transplantation of discordant xenografts: a revew of progress. Immunology 1990; 11: 450-456.

30 Horvat JC, Pecot-Dechavassine M, Mira JC, Davarpanah Y. Formation of functional endplates by spinal axons regenerating through a peripheral nerve graft. Brain Res Bull 1989; 22: 103-114.

31 Zingale A. An experimental model to study axonal regeneration of the rat spinal cord. J Neurosurg Sci 1989; 33: 329-331.

32 Jakerman LB, Reier PJ. Axonal projections between fetal spinal cord transplants and the adult rat spinal cord: a neuroanatomical tracing study of local interactions. J Comp Neurol 1991; 307: 311-334.

33 Sugar O, Gerard W. Spinal cord regeneration in the rat. J Neurophysiol 1940; 3: 1-19.

34 Windle. Spinal cord regeneration associated with a cellular reaction induced by administration of a purified bacterial pyrogen. Proceedings of Fifth International Anatomy Congress 1950. 
35 Kao C, Shimizu Y, Perkins L. Experimental use of cultured cerebellar cortical tissue to inhibit the collagenous scar following spinal cord transection. J Neurosurg 1970; 33: 127-139.

36 Kao C, Change L, Bloodworth. Axonal regeneration across transected mammalian spinal cords: An electron microscopic study of delayed microsurgical nerve grafting. Exp Neurol 1977; 54: 591-615.

37 Schnell L, Schwab M. Axonal regeneration in the rat spinal cord produced by an antibody against myelin-associated neurite growth inhibitors. Nature 1990; 343: 269-272. 